Загреба М. М. [1; ORCID ID: 0000-0003-0440-2106], к.е.н., доцент кафедри економічної теорії, маркетингу та економічної кібернетики,

Вишневська В. А. [1; ORCID ID: 0000-0003-4343-2455], к.е.н., доцент кафедри економічної теорії, маркетингу та економічної кібернетики,

Дмитришин Б. В. ${ }^{[1 ; 0 R C I D ~ I D: ~ 0000-0002-9519-0104], ~}$ к.е.н., доцент кафедри економічної теорії, маркетингу та економічної кібернетики

${ }^{1}$ Центральноукраїнський національний технічний університет, м. Кропивницький

\title{
ПЛАНУВАННЯ ТА ПРОГНОЗУВАННЯ ДІЯЛЬНОСТІ ПІДПРИЕМСТВА В УМОВАХ ГЛОБАЛЬНОї ПАНДЕМІї
}

В статті описано шляхи поширення пандемії COVID-19 в світі та в Україні, а також негативний вплив, що вона здійснює на економіку та інші сфери суспільного життя. Розглянуто обмежувальні заходи, що здійснюються урядами країн по відношенню до бізнесу в умовах карантину та співвідношення позитивних $\mathrm{i}$ негативних наслідків даних заходів. Досліджено втрати української економіки від протиепідемічних заходів в абсолютних цифрах та у відсотках ВВП, а також дано прогноз щодо підсумкових втрат за 2020 календарний рік. Оцінено вплив форсмажорних обставин на планування бізнесу, зокрема особливості використання підходів та моделей бізнес-планування в сучасних умовах. Запропоновано методи прогнозування та прийняття рішень в контексті пандемії у різних сферах діяльності підприємства 3 використанням сучасних інформаційних технологій.

Ключові слова: пандемія COVID-19; планування діяльності підприємства; втрати національної економіки; моделі бізнес-планування; методи прогнозування; системи прийняття рішень.

Актуальність проблеми дослідження. 2020 рік ознаменувався початком однієї з наймасштабніших пандемій в історії людства, що вже проникла у 215 країн і територій та забрала життя більш ніж 1,1 млн людей. Окрім здоров'я населення, вона здійснює неминучий негативний вплив на економіку як окремих підприємств i домогосподарств, так i держав в цілому. Вимушені обмежувальні заходи перешкоджають нормальному веденню бізнесу та примушують використовувати нетривіальні підходи до планування та 
прийняття рішень. А прогнозування мікро- та макроекономічних показників стає задачею підвищеного рівня складності.

Аналіз досліджень і публікацій. Питанням бізнес-планування та прогнозування економічних процесів присвятили праці Т. В. Меркулова [9], К.Барроу, Д. Бористайн, Р.Браун, П. Пруетт, С. Ф. Покропивний [10], Т.Г. Васильців [7], Л. О. Бескровна [6], С. М. Соболь, О. Г. Дерев'янко та ін.

Метою статті $€$ обґрунтування застосування методів прогнозування та планування в економіці в умовах глобальних кризових процесів.

Виклад основного матеріалу. Пандемія COVID-19, також відома як пандемія коронавірусу, $€$ триваючою пандемією коронавірусної хвороби 2019 (COVID-19), спричиненою передачею важкого гострого респіраторного синдрому коронавірусу 2 (SARSCoV-2), який вперше був виявлений у грудні 2019 року в Ухані, Китай. Епідемія була оголошена надзвичайною ситуацією, пов'язаною 3 громадським здоров'ям, у січні 2020 року, а пандемією - у березні 2020 року. Станом на 22 жовтня 2020 року було підтверджено понад 41,2 мільйона випадків захворювання, причому понад 1,13 мільйона смертей приписують COVID-19 [1].

Пандемія спричинила глобальний соціальний та економічний зриви, включаючи найбільшу глобальну рецесію 3 часів Великої депресії. Це призвело до перенесення або скасування спортивних, релігійних, політичних та культурних подій, широкого дефіциту поставок, голодомору, що зачіпає сотні мільйонів людей, та зменшення викидів забруднюючих речовин та парникових газів. Навчальні заклади були закриті частково або повністю, багато з них перейшли на дистанційне навчання.

Спалах захворювання є значною дестабілізуючою загрозою для світової економіки. Оцінка експерта Вашингтонського університету в Сент-Луїсі дала 300 мільярдів доларів впливу на світовий ланцюг поставок, який може тривати до двох років [5]. Світові фондові ринки впали 24 лютого через значне зростання кількості випадків захворювання на COVID-19 за межами Китаю. 27 лютого через посилене занепокоєння щодо спалаху коронавірусу американські фондові індекси зафіксували найсильніші падіння з 2008 року, при цьому Dow впав на 1191 пункт (найбільше одноденне падіння після фінансової кризи 2007-08) і всі три основні індекси в кінці тижня зменшилися більш ніж на 10 відсотків. 28 лютого Scope Ratings $\mathrm{GmbH}$ підтвердила суверенний кредитний рейтинг Китаю, але зберегла негативні прогнози. Акції знову подешевшали через побоювання 
коронавірусу, найбільше падіння припало на 16 березня [2].

Пандемія поширилася на Україну, коли було підтверджено перший у країні випадок госпіталізації в Чернівецькій області 3 березня 2020 року, чоловіка, який подорожував 3 Італії до Румунії на літаку, а потім прибув до України на автомобілі.

11 березня 2020 Кабінет міністрів прийняв постанову «Про запобігання поширенню на території України коронавірусу COVID19», якою на території України встановлено карантин 3 12 березня до 3 квітня 2020 р.

Було заборонено масові заходи (понад 200 осіб, крім заходів, необхідних для роботи органів влади й місцевого самоврядування), закриті дитсадки, заклади освіти. Спортивні заходи дозволено проводити без участі глядачів. Карантин запроваджено у всіх областях, окрім того, з 219 контрольнопропускних пунктів відкритими залишили 49.

316 березня Україна закрила кордон для в"їзду іноземців. 3 опівночі 17 березня на 14 днів (до 3 квітня 2020 року) закрите міжнародне авіаційне, залізничне й автобусне сполучення.

318 березня в Україні призупинене залізничне, авіа- й автобусне сполучення, міжміські і міжобласні пасажирські перевезення, у Харкові, Дніпрі та Києві було закрито метрополітен.

20 березня було оголошено надзвичайну ситуацію в Київській області, Чернівецькій області, Житомирській області, Дніпропетровській області, Івано-Франківській області та місті Києві.

2 квітня 2020 року Кабмін постановою № 255 виклав в новій редакції постанову № 211 КМУ «Про запобігання поширенню на території України гострої респіраторної хвороби COVID-19, спричиненої коронавірусом SARS-CoV-2», чим жорсткіше обмежив свободу громадян, зокрема було заборонено відвідувати зони відпочинку, пересуватись групами тощо.

11 травня відбулося послаблення карантину - відкриті парки та сквери, стоматології, непродовольчі магазини, перукарні тощо.

310 червня 2020 року в Україні дозволяється відкривати заклади культури та проводити культурні заходи. Робота кінотеатрів та функціонування фан-зон на концертах наразі залишається під забороною.

У серпні кількість випадків почала стрімко зростати. Уряд прийняв деякі жорсткіші заходи, наприклад, закриття кордонів країни. У середині вересня в"їзд в Україну був заблокований для 
понад 1000 єврейських паломників-хасидів, які намагалися в"їхати до країни з Білорусі.

За інформацією Державної служби статистики України [9], фінансовий результат підприємств до оподаткування (крім малих і сільськогосподарських підприємств) за I півріччя 2020 р. становить 29,2 млрд грн прибутку, що у 7,5 рази менше, ніж за аналогічний період $2019 \mathrm{p}$.

Прибутковими підприємствами, частка яких у загальній кількості становила 63,4\%, отримано 262,4 млрд грн прибутку, що на 10,1\% менше ніж за I півріччя 2019 р.

Частка збиткових підприємств у порівнянні з відповідним періодом попереднього року зросла на 11,7 в.п. і становила $36,6 \%$. Цими підприємствами допущено 233,2 млрд грн збитків, що по відношенню до аналогічного періоду 2019 р. більше у 3,2 рази.

Значна частка збиткових підприємств спостерігалась у таких видах економічної діяльності: тимчасове розміщування й організація харчування (75,9\%); операції з нерухомим майном $(60,7 \%)$; транспорт, складське господарство, поштова та кур'єрська діяльність (54,3\%); промисловість (38,7\%).

У січні-серпні 2020 р. порівняно із січнем-серпнем 2019 р. індекс промислової продукції становив 92,6\%.

У добувній промисловості і розробленні кар'єрів випуск продукції скоротився на $4,8 \%$.

У переробній промисловості випуск промислової продукції зменшився на 9,0\%.

У текстильному виробництві, виробництві одягу, шкіри, виробів зі шкіри та інших матеріалів індекс промислової продукції становив 86,0\%.

у металургійному виробництві, виробництві готових металевих виробів, крім машин і устаткування, випуск продукції зменшився на $13,2 \%$.

У машинобудуванні індекс промислової продукції становив $77,9 \%$.

У постачанні електроенергії, газу, пари та кондиційованого повітря випуск промислової продукції скоротився на 5,3\%.

Внутрішній валовий продукт України в другому кварталі 2020 року скоротився на $11,4 \%$ порівняно 3 таким самим кварталом попереднього року. Порівняно з першим кварталом цього року падіння становило 9,9\% (з урахуванням сезонного фактору).

ЄБРР погіршив прогноз падіння українського ВВП у 
2020 році до $5,5 \%$ з наступним відновленням на $3 \%$ у 2021 році. У МВФ очікують спаду ВВП України на $7,7 \%$ за підсумками поточного року.

В таких критичних умовах використання методів бізнеспланування має свої особливості.

Процес планування $€$ невід'ємним природним елементом управління створенням, функціонуванням та розвитком кожного економічного агента, адже дозволяє не лише передбачити найбільш важливі економічні характеристики та параметри господарювання, але й узгодити місію та цілі, стратегію і тактику розвитку підприємства, його ресурсний потенціал та можливості її реалізації.

Бізнес-планування - це об'єктивна оцінка власної підприємницької діяльності підприємства, фірми і водночас необхідний інструмент проєктно-інвестиційних рішень відповідно до потреб ринку [6, С. 16].

Важливо зауважити, що бізнес-план на відміну від інших планових документів підприємства стосується:

- планування започаткування та реалізації окремого бізнеспроєкту підприємства;

- планування окремих напрямів, видів економічної діяльності чи створення окремого стратегічного підрозділу підприємства;

- обґрунтування перспективних напрямів розвитку фінансовогосподарської діяльності суб'єкта господарювання.

Відповідно бізнес-план розробляється підприємством перед його створенням (для обґрунтування доцільності інвестицій та ефективності господарювання, а також розміру статутного капіталу); для планування розвитку (у випадку діючого підприємства); для обґрунтування економічної доцільності започаткування нових видів діяльності чи створення нових стратегічних господарських підрозділів, бізнес-одиниць підприємства) [7, С. 10].

Бізнес-план $є$ документом, який містить систему ув'язаних в часі та просторі та узгоджених з метою і ресурсами заходів і дій, спрямованих на отримання прибутку, внаслідок реалізації підприємницького проєкту. Це результат планування, зафіксований у стислій та зрозумілій формі документа. Він виступає інструментом досягнення мети, що включає всі основні напрями діяльності підприємства [10, С. 6].

у більшості випадків стандартне бізнес-планування відбувається в спокійних умовах звичайної діяльності підприємства. Коли ж цей процес відбувається в умовах кризи, то зазвичай він дуже сильно відрізняється від традиційного бізнес-планування. При цьому ще й важливо, щоб його продуманість і раціональність не 
поступалися, а в ідеалі перевершували класичний бізнес-план.

Але якраз в кризовій ситуації у менеджменту компанії, як правило, немає часу для спокійного детального опрацювання кожного пункту плану, а всі рішення повинні прийматися в стислий термін. Звідси і виникає перша і головна вимога до процесу розробки антикризового бізнес-плану - оперативність складання.

Складання антикризового бізнес-плану має починатися 3 аналізу причин, що призвели до поточної кризи. Адже фактично їх нейтралізація $\epsilon$ першою метою антикризового управління. Чим раніше почнеться цей процес, тим швидше і простіше організація зможе подолати кризу.

Незважаючи на те що у випадку з пандемією COVID-19, здавалося б, причина і так зрозуміла, ми все ж перерахуємо основні вимоги до процесу діагностики причин:

- в процесі виявлення причин кризи та формуванні висновків повинні брати участь представники всіх підрозділів підприємства;

- пильна увага повинна бути приділена всім виявленим причинам і фактам, в тому числі малозначним;

- діагностика повинна бути оперативною і займати в ідеалі не більш одного дня;

- по кожному виявленому «вузькому місцю» необхідно сформулювати свої шляхи вирішення - як мінімум такі, що мають конкретні орієнтири і терміни вирішення.

По закінченню діагностики потрібно обов'язково скласти короткий звіт, який розкриває причини кризи, що настала. У ньому досить викласти основні тенденції, яких буде достатньо для розуміння ситуації, що склалася і постановки цілей, які дозволять вийти з кризи. Також він повинен мати достатньо інформації для розробки оперативних рішень, які допоможуть менеджменту досягти поставлених цілей.

Від того, наскільки чітко, доступно і вчасно будуть сформульовані цілі, залежить результат планованих дій. Також дуже важливо правильно донести сформульовані цілі до тих людей, які будуть займатися їх втіленням. Цілі повинні бути досяжними, при цьому дуже важливо не допустити ні заниження, ні завищення вимог.

Чітко розуміючи становище, в якому перебуває підприємство, важливо також визначити, на який період складається бізнес-план. Одна з ключових особливостей антикризового бізнес-планування план повинен складатися на мінімальний період.

Як правило, під час кризи план доводиться переглядати частіше ніж в нормальних умовах. Таким чином, реалізація спільної 
стратегії повинна бути розподілена на кілька невеликих періодів. При цьому проміжні плани можна і навіть потрібно коригувати, при цьому стратегія повинна залишатися незмінною.

Очікувані значення під час кризи рекомендується визначати щомісяця, хоча все досить індивідуально. Головне, щоб досягнення єдиної мети не доходило до абсурду - цілком нормальною може бути ситуація, коли зовнішні і внутрішні умови змінюються настільки, що орієнтуватися на спочатку поставлене завдання стає просто неможливо.

Коли причини кризи виявлені, а на їх основі сформульовані стратегічні та оперативні цілі, можна вважати, що менеджмент підприємства готовий до складання антикризового бізнес-плану. Його розробкою повинні займатися не більше двох осіб, які візьмуть на себе систематизацію та структурування інформації, отриманої на всіх рівнях управління. При цьому вони не повинні займатися самостійний пошуком і обробкою даних. По суті, формується так званий внутрішній проєктний офіс із впровадження антикризового бізнес-плану.

Антикризовий бізнес-план повинен насамперед допомагати менеджерам компанії в найбільш ефективному здійсненні їх функцій. Звідси і чергова вимога до нього: вся інформація повинна бути чітко структурована і представлена в найбільш зручному для сприйняття вигляді. Чим більше розрахунків здійснюється на підприємстві і чим більше імітаційних моделей при цьому використовується, тим менш прозорим стає планування.

Таким чином, важлива не кількість сторінок бізнес-плану, а їх зміст. Загальні вимоги ті ж, що і в звичайних умовах, - доступність і простота викладу, достатність, надійність і достовірність інформації. В умовах кризи ця вимога має особливе значення в силу екстремальних умов діяльності і нестачі часу на прийняття рішення.

Основними помилками при складанні та реалізації антикризового бізнес-плану є:

- нечітке викладення цілей;

- надлишок технічної інформації;

- виявлення того, що потрібно зробити, без чіткої вказівки, як це зробити;

- недостатньо точний розподіл і неузгодженість відповідальності;

- відхилення від дійсності і надмірне перебільшення власних можливостей;

- відсутність належного контролю за виконанням бізнес-плану (точки контролю не встановлені); 
- неузгодженість в діях при складанні та виконанні бізнесплану;

- відведення надмірної кількості часу «паперовій» роботі.

Бізнес-план $€$ універсальним інструментом планування та дозволяє вирішувати значну кількість різних за характером завдань. Тому бізнес-плани як документи можуть значною мірою відрізнятись один від одного за формою, змістом, структурою, обсягами і т. д. В Україні законодавчо не визначено обов'язкову форму та структуру бізнес-плану. Але незважаючи на це, існують загальні рекомендації для написання проєкту бізнес-плану. Вони ґрунтуються на використанні відповідних методик та методів планування. Міжнародні стандарти, які найбільш часто використовуються у бізнес-плануванні, розроблені організацією United Nations Industrial Development Organization (UNIDO), Європейським банком реконструкції й розвитку (ЄБРP) та консалтинговою компанією KPMG (таблиця). Порівняння пропонованої структури бізнес-планів дозволяє виокремити типові розділи бізнес-плану.

Таблиця

Структура бізнес-плану за міжнародними стандартами

\begin{tabular}{|c|c|c|}
\hline UNIDO & KPMG & ЄБРР \\
\hline 1 & 2 & 3 \\
\hline 1. Резюме & 1. Титульний лист & 1. Титульний лист \\
\hline $\begin{array}{l}\text { 2. Опис галузі й } \\
\text { компанії }\end{array}$ & $\begin{array}{l}\text { 2. Меморандум про } \\
\text { конфіденційність }\end{array}$ & $\begin{array}{l}\text { 2. Меморандум про } \\
\text { конфіденційність }\end{array}$ \\
\hline $\begin{array}{l}\text { 3. Опис послуг } \\
\text { (товарів) }\end{array}$ & $\begin{array}{l}\text { 3. Резюме } \\
\text { 3.1. Короткий огляд } \\
\text { 3.2. Пропонована } \\
\text { продукція й послуги } \\
\text { 3.3. Місія, цілі й завдання }\end{array}$ & 3. Резюме \\
\hline $\begin{array}{l}\text { 4. Продажі і } \\
\text { маркетинг }\end{array}$ & $\begin{array}{l}\text { 4. Продукція й послуги } \\
\text { 4.1. Вступ } \\
\text { 4.2. Продукція й послуги } \\
\text { 4.3. Супутні товари й } \\
\text { послуги }\end{array}$ & $\begin{array}{l}\text { 4. Підприємство } \\
\text { 4.1. Історія розвитку } \\
\text { підприємства і його стан } \\
\text { на момент створення } \\
\text { бізнес-плану } \\
\text { 4.2. Власники, керівний } \\
\text { персонал, працівники } \\
\text { підприємства } \\
\text { 4.3. Поточна діяльність } \\
\text { 4.4. Фінансовий стан } \\
\text { 4.5. Кредити }\end{array}$ \\
\hline
\end{tabular}


продовження таблиці

\begin{tabular}{|c|c|c|}
\hline $\begin{array}{l}\text { 5. План } \\
\text { виробництва }\end{array}$ & $\begin{array}{l}\text { 5. Аналіз ринку й галузі } \\
\text { 5.1. Використання продукту } \\
\text { й послуги } \\
\text { 5.2. Демографічний аналіз } \\
\text { 5.3. Конкуренція }\end{array}$ & $\begin{array}{l}\text { 5. Проєкт } \\
\text { 5.1. Загальна інформація } \\
\text { про проєкт } \\
\text { 5.2. Інвестиційний план } \\
\text { проєкту }\end{array}$ \\
\hline & 5.4. SWOT-аналіз & $\begin{array}{l}\text { 5.3. Аналіз ринку, } \\
\text { конкурентоспроможність } \\
\text { 5.4. Опис виробничого } \\
\text { процесу } \\
\text { 5.5. Фінансовий план } \\
\text { 5.6. Екологічна оцінка }\end{array}$ \\
\hline $\begin{array}{l}6 . \\
\text { Організаційний } \\
\text { план }\end{array}$ & $\begin{array}{l}\text { 6. Цільові ринки } \\
\text { 6.1. Цільові споживачі } \\
\text { 6.2. Географія цільового } \\
\text { ринку } \\
\text { 6.3. Ціноутворення }\end{array}$ & $\begin{array}{l}\text { 6. Фінансування } \\
\text { 6.1. Графіки одержання й } \\
\text { погашення кредитних } \\
\text { коштів } \\
\text { 6.2. Застава й поручництво } \\
\text { 6.3. Обладнання й роботи, } \\
\text { які будуть фінансуватися за } \\
\text { рахунок кредитних коштів } \\
\text { 6.4. SWОТ-аналіз } \\
\text { 6.5. Ризики й заходи щодо } \\
\text { їх зниження }\end{array}$ \\
\hline $\begin{array}{l}\text { 7. Фінансовий } \\
\text { план }\end{array}$ & $\begin{array}{l}\text { 7. Стратегії реклами й } \\
\text { просування } \\
\text { 7.1. Стратегія просування } \\
\text { 7.2. Способи поширення } \\
\text { реклами } \\
\text { 7.3. Прогноз продажів }\end{array}$ & 7. Додатки \\
\hline $\begin{array}{l}\text { 8. Оцінка } \\
\text { ефективності } \\
\text { проєкту }\end{array}$ & $\begin{array}{l}\text { 8. Управління } \\
\text { 8.1. Організація й основний } \\
\text { персонал } \\
\text { 8.2. Постійне споживання } \\
\text { активів } \\
\text { 8.3. Витрати на підготовку } \\
\text { виробництва }\end{array}$ & \\
\hline $\begin{array}{l}\text { 9. Гарантії й } \\
\text { ризики компанії }\end{array}$ & $\begin{array}{l}\text { 9. Фінансовий аналіз } \\
\text { 9.1. Собівартість } \\
\text { реалізованої продукції } \\
\text { 9.2. Аналіз беззбитковості } \\
\text { 9.3. Кількісний аналіз } \\
\text { 9.4. Доходи й витрати } \\
\text { 9.5. Рух грошових коштів } \\
\text { 9.6. Баланси підприємства } \\
\text { 9.7. Ризики }\end{array}$ & \\
\hline 10. Додатки & 10. Додатки & \\
\hline
\end{tabular}

Джерело: складено авторами на основі [3; 4; 11$]$ 
Організація, відповідно до особливостей своєї діяльності та вимог замовника, має можливість обрати відповідну стандартну методику бізнес-планування (на основі міжнародних стандартів) або методику, найбільш уніфіковану до специфіки свого проєкту.

Підготовкою основних розділів антикризового бізнес-плану сам процес бізнес-планування не закінчується. Протягом усього планового періоду потрібно постійно контролювати виконання плану, розраховувати відхилення планових показників від фактичних і аналізувати причини таких відхилень. Для аналізу виконання бізнес-плану частіше за все використовуються ранжування, факторний аналіз та «план-факт» аналіз.

На нашу думку, з огляду на важливість управлінських рішень, що приймаються в умовах кризи, невиконання бізнес-плану може призвести до зриву загальної стратегії антикризового управління. Тому грамотна система бізнес-планування відіграє дуже важливу, можна сказати визначальну роль в системі антикризового управління будь-якої компанії.

Далі розглянемо підходи до моделювання та прогнозування економічних процесів в умовах пандемії. Насамперед зосередимо увагу на понятті часових рядів, що $\epsilon$ основою побудови прогнозних моделей.

Динамічні процеси, що відбуваються в економіці, найчастіше проявляються у вигляді ряду послідовних, розташованих у хронологічному порядку, значень того чи іншого показника, який своїми зміненнями відображує хід розвитку економічних явищ. Ці значення можуть бути використані для обґрунтування (або спростування) різних моделей соціально-економічних систем. Вони служать також базою для розробки прогнозних моделей.

Аналіз динаміки часового ряду включає наступні послідовні задачі:

1. Коректування рівнів динамічного ряду, якщо цього вимагають умови порівняльності.

2. Визначення систематичних компонент динамічного ряду, які присутні у його розкладенні.

3. Розрахунок оцінок тих функцій, які входять в розкладення часового ряду.

4. Підбір моделі, яка адекватно описує поведінку випадкової компоненти, і статистичне оцінювання параметрів цієї моделі.

Цей процес прийнято називати ідентифікацією моделі. Вдалий розв'язок задач 1-4 є основою для побудови коротко- $\mathrm{i}$ середньострокових прогнозів рівнів часового ряду. 
В умовах глобальних кризових процесів в державі особливої актуальності набуває попереднє згладжування рівнів часових рядів при побудові моделей та прогнозів. Існує цілий ряд методів згладжування - згладжування по двом точкам, методи простої та зваженої ковзкої середньої, методи екстраполяції на основі кривих зростання тощо. Проте в ситуації поточної пандемії автори вважають найбільш прийнятним метод простого експоненційного згладжування.

Ідея методу полягає в згладжуванні часового ряду ковзкою середньою 3 експоненційними вагами. Така середня більше характеризує значення процесу наприкінці інтервалу згладжування, ніж на початку. У випадку, коли найбільша вага надається останньому спостереженню, а вага решти спадає геометрично, одержане в результаті середнє відоме як експоненційно зважене середнє, або експоненційно згладжений ряд. Для всіх рівнів ряду, починаючи з першого і закінчуючи моментом часу $\mathrm{t}$, можна записати:

$$
\hat{y}_{t+1}=\alpha y_{t}+(1-\alpha) \cdot y_{t},
$$

де $(1-\alpha)$ - коефіцієнт дисконтування.

Коефіцієнт $\alpha$ визначає швидкість, $з$ якою нове згладжене значення рівня ряду пристосовується до помилки, якщо $\alpha=0$, то пристосування немає, якщо ж $\alpha=1$, то має місце повне пристосування.

В умовах нестабільної макроекономічної ситуації, що спостерігається зараз, автори рекомендують застосування значень $\alpha$ в межах 0,1-0,2.

Для побудови прогнозу за експоненційно зваженим середнім необхідно задати лише початкову оцінку прогнозу; подальше прогнозування робиться автоматично із надходженням нових даних спостережень і не потрібно обчислювати прогноз, починаючи спочатку, як це було необхідно за методом ковзкої середньої. Чутливість експоненційно зваженого середнього 3 метою підвищення адекватності прогнозної моделі може бути в будь-який час змінена шляхом змінення величини $\alpha$.

Після згладжування наступає етап безпосередньої побудови моделей прогнозування. Проте застосування більшості класів таких моделей може виявитися некоректним в умовах різких змін у макроекономічній ситуації, викликаних, зокрема, протиепідемічними заходами. Саме тому автори рекомендують зосередити увагу на адаптивних методах. 
Адаптивні методи прогнозування застосовуються в ситуації змінення зовнішніх умов, коли найбільш важливими стають останні реалізації досліджуваного процесу.

Загальна схема побудови адаптивних методів може бути представлена наступним чином. За кількома першими рівнями ряду будується модель і оцінюються ії параметри. На основі побудованої моделі розраховується прогноз на один крок вперед, причому його відхилення від фактичного рівня ряду розцінюється як помилка прогнозування, яка враховується відповідно до прийнятої схеми коректування моделі. Далі за моделлю 3 відкоректованими параметрами розраховується прогнозна оцінка на наступний момент часу тощо. Таким чином, модель постійно вбирає в себе нову інформацію і до кінця періоду навчання відбиває тенденцію розвитку процесу, що існує на даний момент. Прогноз отримується як екстраполяція останньої тенденції. Численні адаптивні методи відрізняються один від одного лише способами числової оцінки параметрів моделі і визначення параметрів адаптації.

Оптимальним вважається найкращий прогноз, який можна одержати за наявних обставин. Часто його називають прогнозом раціональних сподівань. Оптимальний прогноз - це передбачення, яке використовує всю доступну на момент побудови прогнозу інформацію, зроблено на основі економічної теорії.

В умовах пандемії слід приділяти особливу увагу якісним оцінкам прогнозів, частіше перевіряти відповідність значень попередніх прогнозів поточній ситуації, за необхідності зменшувати інтервали часових рядів, а також застосовувати ретроспективний аналіз перед впровадженням нових методів, використовуючи попередні періоди для тестування їхньої ефективності.

Висновки. Глобальна пандемія, що охопила світ в 2020 році, безумовно, увійде в історію не лише медицини, але й економіки. їі наслідки для світових фондових та валютних ринків важко переоцінити. Починаючи з березня цього року, криза охопила i Україну, викликавши необхідність комплексних непопулярних заходів протидії і, як наслідок, втрати 5,5-7,7\% ВВП.

Планування та прогнозування бізнесу в таких умовах $\epsilon$ нетривіальною задачею. Бізнес-план охоплює практично всі функціональні напрями суб'єкта господарювання, починаючи від детального опису технології бізнес-проєкту і закінчуючи ґрунтовними фінансовими розрахунками ефективності 
підприємницької діяльності. Тому його розробка і контроль реалізації (в подальшому) значно сприяє як підвищенню ефективності, так і зниженню ризиків у період економічної кризи. Що стосується прогнозування, то тут автори рекомендують застосування експоненційного згладжування, адаптивних моделей та посилене оцінювання оптимальності вибраних методів.

Перспективним зараз може бути використання у прогнозуванні нейронних мереж, що навчатимуться на реальних змінах в економіці та екстраполюватимуть їх на майбутнє й інші подібні випадки.

1. Coronavirus Update. URL: https://www.worldometers.info/coronavirus/ (дата звернення: 22.09.2020). 2. Grim Economic Outlook Grips Markets as Stocks Plummet. The New York Times. URL: https://www.nytimes.com/2020/03/16/business/stock-market-dropsrecap.html (дата звернення: 22.09.2020). 3. KPMG : official website. URL: http://www.kpmg.com (дата звернення: 22.09.2020). 4. The European Bank for Reconstruction and Development : official website. URL: http://www.ebrd.com (accessed: 22.08.2020). 5. WashU Expert: Coronavirus far greater threat than SARS to global supply chain. URL: https://source.wustl.edu/2020/02/washuexpert-coronavirus-far-greater-threat-than-sars-to-global-supply-chain/

(accessed: 22.08.2020). 6. Бескровна Л. О. Бізнес-планування підприємства : навч. посіб. Одеса : ОНАЗ ім. О.С. Попова, 2012. 124 с. 7. Бізнес-планування підприємницької діяльності : навч. посіб. / Варналій 3. С., Васильців Т. Г., Лупак Р.Л. та ін. Чернівці : Технодрук, 2019. 264 с. 8. Державна служба статистики України: офіц. сайт. URL: http://www.ukrstat.gov.ua/ (дата звернення: 22.09.2020). 9. Меркулова Т. В., Лубенець С. В. Прогнозування соціально-економічних процесів : навч.-метод. посіб. Харків : ХНУ ім. В.Н. Каразіна, 2017. 87 с. 10. Бізнес-план: технологія розробки та обґрунтування : навч. посіб. / Покропивний С. Ф., Соболь С. М., Швиданенко Г. О. та ін. Вид. 2-ге, доп. Київ : КНЕУ, 2002. 379 с. 11. Стандарты UNIDO для бизнес-плана. URL: http://www.foruminvestor.com/files/UNIDO_standards.pdf (дата звернення: 22.09.2020).

\section{REFERENCES:}

1. Coronavirus Update. URL: https://www.worldometers.info/coronavirus/ (data zvernennia: 22.09.2020). 2. Grim Economic Outlook Grips Markets as Stocks Plummet. The New York Times. URL: https://www.nytimes.com/2020/03/16/business/stockmarket-drops-recap.html (data zvernennja: 22.09.2020). 3. KPMG : official website. URL: http://www.kpmg.com (data zvernennja: 22.09.2020). 4. The European Bank for Reconstruction and Development : official website. URL: http://www.ebrd.com (accessed: 22.08.2020). 5. WashU Expert: Coronavirus far greater threat than SARS to global supply chain. URL: https://source.wustl.edu/2020/02/washu-expertcoronavirus-far-greater-threat-than-sars-to-global-supply-chain/

(accessed: 22.08.2020). 6. Beskrovna L. O. Biznes-planuvannia pidpryiemstva : navch. posib. Odesa : ONAZ im. O. S. Popova, 2012. 124 c. 7. Biznes-planuvannia pidpryiemnytskoi diialnosti : navch. posib. Varnalii Z. S., Vasyltsiv T. H., Lupak R. L. ta in. Chernivtsi : Tekhnodruk, 2019. 264 c. 8. Derzhavna sluzhba statystyky Ukrainy : ofits. sait. URL: 
http://www.ukrstat.gov.ua/ (data zvernennja: 22.09.2020). 9. Merkulova T. V., Lubenets S. V. Prohnozuvannia sotsialno-ekonomichnykh protsesiv : navch.-metod. posib. Kharkiv : KhNU im. V. N. Karazina, 2017. 87 c. 10. Biznes-plan: tekhnolohiia rozrobky ta obgruntuvannia : navch. posib. Pokropyvnyi S. F., Sobol S. M., Shvydanenko H. O. ta in. Vyd. 2-he, dop. Kyiv : KNEU, 2002. 379 c. 11. Standartyi UNIDO dlya biznes-plana. URL: http://www.forum-investor.com/files/UNIDO_standards.pdf (data zvernennja: 22.09.2020).

Zahreba M. M. ${ }^{[1 ;}$ ORCID ID: 0000-0003-0440-2106], Candidate of Economics (Ph.D.), Associate Professor, Department of Economic Theory, Marketing and Economic Cybernetics,

Vyshnevska V. V. [1; ORCID ID: 0000-0003-4343-2455], Candidate of Economics (Ph.D.), Associate Professor, Department of Economic Theory, Marketing and Economic Cybernetics, Dmytryshyn B. V. [1; ORCID ID: 0000-0002-9519-0104], Candidate of Economics (Ph.D.), Associate Professor, Department of Economic Theory, Marketing and Economic Cybernetics

${ }^{1}$ Central Ukrainian National Technical University, Kropyvnytskyi

\section{ENTERPRISE PLANNING AND FORECASTING IN A GLOBAL PANDEMIC}

The article describes the ways of spreading the COVID-19 pandemic in the world and in Ukraine, as well as the negative impact it has on the economy and other spheres of public life. The scale of the spread of the virus was assessed both on a territorial basis and on the affected population. Some indicators of the economic crisis caused by the pandemic are presented, as well as expert forecasts regarding the depth and timing of its continuation. The restrictive measures taken by the governments of the countries in relation to business in the conditions of quarantine and a ratio of positive and negative consequences of these measures are considered. The most common measures were the closure of external borders, limiting the number and opening hours of public catering establishments, and promoting personal hygiene. The losses of the Ukrainian economy from anti-epidemic measures in absolute numbers and as a percentage of GDP are studied, as well as a forecast of the final losses for the $\mathbf{2 0 2 0}$ calendar year is given. It is based on the data of the State Statistics Service of Ukraine, which show a significant drop in most sectors of the economy, in particular, the financial result of enterprises, the percentage of unprofitable enterprises, the index of industrial production, the supply of energy resources, etc. The influence of force majeure circumstances on business planning is estimated, in particular the peculiarities of using business planning approaches and models in modern conditions. Methods of forecasting and decision-making in the context of a pandemic in various spheres of enterprise activity with the 
use of modern information technologies are offered. In particular, the using of time series dynamics analysis, exponential smoothing, adaptive models is considered.

Keywords: COVID-19 pandemic; enterprise activity planning; losses of national economy; business planning models; forecasting methods; decisionmaking systems.

Загреба М. М. [1; 0RCID ID: 0000-0003-0440-2106], к.э.н., доцент кафедры экономической теории, маркетинга и экономической кибернетики,

Вишневская В. А. [1; ORCID ID: 0000-0003-4343-2455], к.э.н., доцент кафедры экономической теории, маркетинга и экономической кибернетики,

Дмитришин Б. В. [1; ORCID ID: 0000-0002-9519-0104], к.э.н., доцент кафедры экономической теории, маркетинга и экономической кибернетики

${ }^{1}$ Центральноукраинский национальный технический университет, г. Кропивницкий

\section{ПЛАНИРОВАНИЕ И ПРОГНОЗИРОВАНИЕ ДЕЯТЕЛЬНОСТИ ПРЕДПРИЯТИЯ В УСЛОВИЯХ ГЛОБАЛЬНОЙ ПАНДЕМИИ}

В статье описаны пути распространения пандемии COVID-19 в мире и в Украине, а также негативное влияние, которое она оказывает на экономику и другие сферы общественной жизни. Рассмотрены ограничительные мероприятия, осуществляемые правительствами стран по отношению к бизнесу в условиях карантина и соотношение положительных и отрицательных последствий данных мероприятий. Исследованы потери украинской экономики от противоэпидемических мероприятий в абсолютных цифрах и в процентах ВВП, а также дан прогноз относительно итоговых потерь по итогам 2020 календарного года. Оценено влияние форс-мажорных обстоятельств на планирование бизнеса, в частности особенности использования подходов и моделей бизнес-планирования в современных условиях. Предложены методы прогнозирования и принятия решений В контексте пандемии В различных сферах деятельности предприятия с использованием современных информационных технологий.

Ключевые слова: пандемия COVID-19; планирование деятельности предприятия; потери национальной экономики; модели бизнеспланирования; методы прогнозирования; системы принятия решений. 